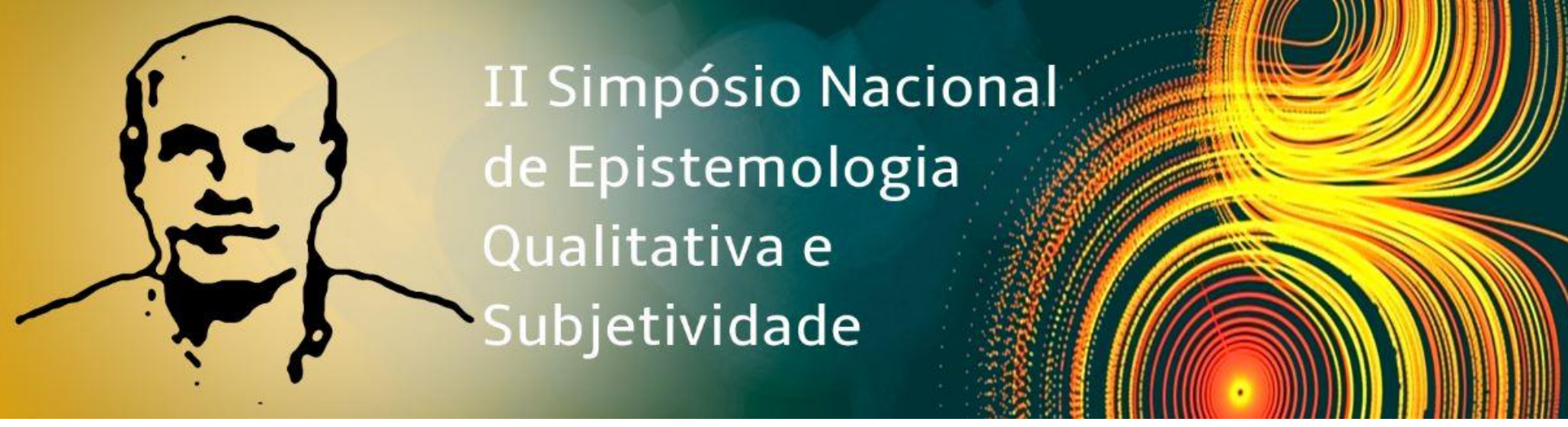

Eixo temático: Subjetividade e Saúde Humana

\title{
Desinstitucionalização e Subjetividade: Um Processo de Articulação Entre Instituições, Profissionais, Usuários e Estratégias em Saúde Mental
}

Larissa Helen Brito Alves - Centro Universitário de Brasília, larissahelen.ideal@gmail.com Daniel Magalhães Goulart - Centro Universitário de Brasília, danielgoulartbr@gmail.com

\section{Resumo}

Nesta apresentação, pretendo explanar algumas questões relevantes em relação à pesquisa de monografia que venho desenvolvendo no âmbito da graduação em psicologia no decorrer de 2019, abordando seus resultados parciais. É importante salientar, como ponto central da pesquisa, a desinstitucionalização no cenário de saúde mental a partir das relações e estratégias desenvolvidas dentro da articulação entre a instituição (CAPS), usuários e profissionais. A partir disso, tem-se como referencial a teoria da subjetividade de Fernando Gonzalez Rey, que possibilita compreender os processos subjetivos individuais e sociais que emergem nessa desinstitucionalização em um CAPS do DF, de modo a favorecer o desenvolvimento subjetivo dos usuários. Em um primeiro momento da apresentação, apresento o processo de desinstitucionalização, que implica a orientação ao desmonte dos manicômios, mas que abrange a transformação das relações de poder entre instituição e indivíduo. Segundo Rotelli (2001), a desinstitucionalização implica buscar reestabelecer a relação do indivíduo com o corpo, com os direitos civis e com os próprios sentimentos. Dessa forma, a atenção psicossocial prestada pelos CAPS pressupõe um acolhimento da pessoa em sofrimento psíquico por meio de um conjunto de ações que visam à substituição da lógica manicomial (YASUI, 2009). Ainda no campo teórico, pontuo como fundamental a compreensão dos desafios enfrentados pelo serviço de Atenção Psicossocial, não somente em uma esfera macro, como financiamento, superlotação, etc., mas em detalhes sutis da própria 
